\title{
The Work of Play in David Foster Wallace's Infinite Jest
}

\author{
MARK BRESNAN
}

\begin{abstract}
Through its treatment of sport, recreation, and leisure, David Foster Wallace's Infinite Jest depicts play as an activity fraught with anxiety, subject to the same disciplinary structures that restrict autonomy in any other individual endeavor. As such, the novel continues a tradition of postmodern sports literature in which playful rebellion is treated with skepticism. Only through a strategic and provisional use of what Donna Haraway has called "serious play" are Infinite Jest's central characters able to construct meaningful autonomy.
\end{abstract}

Keywords: Infinite Jest, play, postmodern sports literature, poststructuralism, tennis, David Foster Wallace

"So they play, logically, cautiously, so earnest and deliberate in their calculations they appear thoroughly and queerly adult, almost Talmudic, from a distance." - Infinite Jest, 327

$\mathrm{n}$ one of the many conversations about tennis interspersed throughout David Foster Wallace's 1996 novel Infinite Jest, Enfield Tennis Academy student Mario Incadenza quizzes Gerhardt Schtitt, the school's head coach and athletic director, on his athletic philosophy. Schtitt admits that much of his thinking on the subject is rooted in his education at a German Gymnasium, that athletics are "basically just training for citizenship" in which the self is forced to submit to both the demands of the team and the rules of a particular game (82). But when Mario points out the individual nature of tennis ("where it's just you v. one other guy"), Schtitt revises his claim: "The true opponent, the enfolding boundary, is the player himself" (83-4). Mario's troubled response- “So what's the difference between tennis and suicide, life and death, the game and its own end?"-forces Schtitt to pause. 
Wallace confronts a similar question in his essay on professional tennis player Michael Joyce, also published in 1996. Reflecting on both the narrow focus of Joyce's childhood and on his apparent lack of any interests outside of tennis, Wallace describes him as a "radically compress[ed]" and even "grotesque" figure (254). Joyce's commitment to the game leads directly to the renunciation of his autonomy; Wallace describes his mien as "the regretless cheer of a man for whom issues of choice became irrelevant long ago" (255). The fictional Enfield Tennis Academy teaches its students that this submission of the will is a crucial component of their success; the narrator describes John Wayne, currently the top-ranked player at E.T.A., as a "grim machine" (438). Why is this "grim" selfabnegation so crucial to tennis, a supposedly "playful" game?

In each of Infinite Jest's three interconnected plots, characters confront dilemmas that require them to renounce their autonomy in order to engage in playful activities, including sports, recreation, and leisure. The residents of Ennet House are recovering alcoholics and drug addicts who have lost control of their lives through their abuse of recreational substances. Despite the often gruesome nature of the lows each resident has experienced, they still cannot overcome their desire for the same substances that led to their confinement in a halfway house. The most explicit confirmation of Mario's suspicion that play ultimately leads to selferasure is an "entertainment" cartridge, also titled Infinite Jest, that transfixes each of its viewers with fatal paralysis. On the surface, it appears that play and autonomy cannot coexist in the world of the novel.

Coach Schtitt, on the other hand, seems unwilling to link the rigors of elite tennis training with the renunciation of the autonomous self. In his conversation with Mario, he proposes that tennis can counteract this tendency toward selfabnegation through its promise of "the chance to play" (84). Schtitt's implication - that play provides a unique opportunity to transcend the limits of the self and to gain a measure of autonomy within the rigid prescriptions and boundaries of the tennis court-explicitly echoes structuralist definitions of play as articulated by Johan Huizinga and Roger Caillois. In his 1944 study Homo Ludens, Huizinga outlines a concept of play that functions as no less than the reclamation of human autonomy from "the absolute determinism of the cosmos" (3). For both Huizinga and Caillois, author of Man, Play, and Games, play is a discrete and centered activity. Both insist on the separateness of play from everyday life as well as its existence within a structure of rules and limits: "All play moves and has its being within a play-ground marked off beforehand either materially or ideally, deliberately or as a matter of course" (Huizinga 10). This "play-ground" represents, for both Huizinga and Caillois, the langue within which the possibilities for play are limitless - as long as the boundaries themselves are not violated. Schtitt's definition of play, through which tennis players maintain a measure of autonomy despite the rigid boundaries of the court, clearly depends on this structuralist framework.

Post-structuralist theories of play question the stability of these rules and limits. In his essay "Structure, Sign and Play in the Discourse of the Human 
Sciences," Jacques Derrida claims that play works to disrupt any totalizing system's boundaries. For Derrida, the field of play has no center, no force "which arrests and grounds the play of substitutions" (289). What play produces, then, is surplus and supplementarity, a process of destabilization that is fundamental to Derrida's concept of writing as différance. While Derrida's definition of play, like that of Caillois and Huizinga, identifies play as a possible site for autonomy, this autonomy is produced by the disruption of a system rather than by adherence to its rules and boundaries. Donna Haraway rearticulates this concept of play, emphasizing the ways in which it can disrupt various identity categories. Noting that "[i]rony is about humor and serious play," Haraway emphasizes the ironic nature of her approach and of the cyborg figure itself (149). Enabled by its uniquely playful conception of the self, Haraway argues that the cyborg figure has "serious potential for changing the rules of the game" and can negotiate seemingly paradoxical conflicts (173).

Infinite Jest interrogates both structuralist and poststructuralist definitions of play. Through its treatment of sport, recreation, and leisure, Infinite Jest depicts play as an activity fraught with anxiety, subject to the same disciplinary structures that restrict autonomy in any other individual endeavor. In fact, the novel characterizes sport as an enterprise completely devoid of play-not only in institutionally organized contests but also in impromptu player-created games. Contra Huizinga and Callois, one cannot speak of sports, as played in Infinite Jest, as being governed by a finite set of rules. Instead, the operative structures governing play go well beyond the "rules of the game," encompassing not only the lines on the court and the procedures for keeping score but also institutional, familial, erotic, political, and many other forces. Recreation and leisure, which we might assume provide opportunities to escape from or destabilize the prevailing order, are equally troubled enterprises. Hal Incadenza, Mario's older brother and star tennis player at E.T.A., is one of many recreational drug users in the novel. Sneaking through a labyrinth of underground tunnels in order to smoke marijuana, Hal assumes that he has escaped the invasive regulations of the tennis academy. But Infinite Jest depicts this and other attempts at destabilization as profoundly banal and joyless enterprises. In these moments, the play of disruption becomes work.

Liberating play does appear in Infinite Jest, but not in any of the places readers might expect to find it - not on the tennis court, on the football field, in entertainment cartridges, or through recreational drug use. Instead, the novel locates liberating play in the seriousness and sobriety of the Alcoholics Anonymous meeting room. Convicted felon Don Gately's recovery from dependence is enabled by the same provisional and playful constitution of the self that Haraway outlines, as it allows his credulity toward the mechanisms of AA to coexist with his fervent desire to remain sober. Yet the tenuous nature of this recovery, as illustrated by Don's frantic attempts to resist Demerol after suffering gruesome gunshot wounds, suggests that serious play also has its limits. 


\section{The Corruption of Play in Postmodern Sports Literature}

One of Infinite Jest's three interconnected plots follows Hal Incadenza, a student at the Enfield Tennis Academy, where, as Sven Birkerts ${ }^{1}$ points out, "nothing much happens" (108). While important competitions are alluded to and briefly described, Wallace devotes far more narrative energy to the apparently extraneous minutiae of life at E.T.A., including the complex competitive philosophies of each player, copiously detailed practice drills, and a bizarre tennis-based geopolitical simulation called Eschaton. This strange emphasis has prompted many critics to either ignore the tennis plot or read it only as a development of the focus on entertainment that unites the rest of the novel. Indeed, E.T.A. students describe turning professional as making "The Show," a spectacle that resonates with academy founder James Incadenza's famous "entertainments." Though the novel clearly associates tennis and entertainment, these readings ignore the skepticism towards play that not only explains Infinite Jest's extraordinary narrative presentation of sport, but also connects it to a significant tradition within postmodern literature that questions the connection between sports and liberating play. Through their focus on the restrictions encountered by the play impulse, Robert Coover's The Universal Baseball Association, J. Henry Waugh, Prop. and Don DeLillo's End Zone illustrate many key characteristics of this tradition; they also provide a useful counterpoint to Infinite Jest, which both echoes and revises their depictions of sports and play. ${ }^{2}$

Universal Baseball Association's Henry Waugh is the inventor of the dice game that he has used to simulate over fifty baseball seasons, each involving eight teams playing seventy games each. The novel's narrative oscillates freely between the "real" Henry, rolling dice and consulting charts in his apartment, and an exuberant account of the baseball game as produced by these dice rolls. Hits and errors are governed by the roll of the dice while Henry's imagination generates context: the roar of the crowd, the pitch locations, and each player's individual mannerisms. Despite his affinity for numbers and statistics (Henry is an accountant), it is this power of narrative that most attracts him to the game: "This done, the posting of all statistics from the day's play, Henry turned to the job he enjoyed most-writing it up in the Book. [. . .] Into the Book went the whole UBA, everything from statistics to journalistic dispatches, from seasonal analyses to general baseball theory" (55). The dice remain purely mechanistic; only through narration can Henry inject a ludic element into the simulation.

But Henry's "playful" narrative is actually strictly governed by the prevailing conventions of sports fiction and journalism. These conventions generate Henry's longing to create what critic Christian Messenger has identified as the "Ritual Sports Hero," a staple of American sports literature from James Fenimore Cooper to Ernest Hemingway (30). This hero, argues Messenger, "has always been a natural aristocrat. [. . .] Before the contemporary era, the figure always had a 
purity of conception, a breadth of vision, and an innocence that made him both vulnerable and heroic" (30). How better to account for Henry's attribution of "incredible poise" and "effortless calm" to Damon Rutherford, son of former UBA star Brock Rutherford (63)? As Roy Caldwell argues, "The true subject of Coover's novel is not the playing of baseball but the making of fiction" (162). Henry has no graphs or charts with which he can structure this narrative "game"; rather, he responds to the diffuse network of power relations that govern him, his creation, and the conventions of sports journalism and fiction.

In Universal Baseball Association, Henry looks to play as a site of stability, an opportunity to exert god-like authority in his otherwise unremarkable life. End Zone's Gary Harkness, on the other hand, quickly perceives his lack of agency within the structure of Logos College's football team:

\begin{abstract}
There were many times, believe it, when I wondered what I was doing in that remote and unfed place, that summer tundra, being hit high and low by a foaming pair of 240-pound Texans. [. . .] Being made to obey the savage commands of unreasonable men. Being set apart from all styles of civilization as I had known or studied them. Being led in prayer every evening, with the rest of the squad, by our coach, warlock and avenging patriarch. (5)
\end{abstract}

Rather than providing a haven for autonomous play, football creates structures of control that proliferate into nearly every aspect of Harkness's life. Acutely aware of these control structures, Harkness continually seeks to destabilize them through other forms of play, notably recreational drug use.

Taking a suggestion from his girlfriend Myna, Harkness smokes marijuana before the season's final game. His performance during the game, though it certainly must have appeared outrageous to any spectators (he leaves the huddle and walks off the field following his team's first play) merits scant narrative attention: "I got up and walked off. I was exceedingly hungry" (174). The overwhelming banality of this short passage sharply contrasts with the over thirty pages devoted to the game against Centrex, for which Harkness is sober; Myna's suggestion that it will be "tremendous to observe all that action from close up and being high" is never fulfilled (167). Furthermore, even Harkness's rebellion against his team is co-opted by the school's sports information director, who senses that Gary's malfeasance constitutes a "human interest thing," featuring a "temperamental star" (177). Coach Creed is also nonplussed, naming Harkness next year's captain on the assumption that he will "settle down" after getting his discontent "off [his] chest" (201). Reacting to Creed, Harkness acknowledges the degree to which his attempted destabilization has failed: "I was now part of the apparatus. No longer did I circle and watch, content enough to be outside the center and even sufficiently cunning to plan a minor raid or two. Now I was the law's small tin glitter" (202).

Despite their obvious differences, Henry Waugh and Gary Harkness both express nostalgia for an earlier time of unfettered play. Henry's memories of his 
first discovery of the game retain an almost Edenic quality. Harkness narrates just such a return to "pure" play (though it is decidedly grittier) when his team gathers for a midafternoon game of pickup football without coaches, spectators, or even huddles: "We were getting extremely basic, moving into elemental realms, seeking harmony with the weather and the earth" (195). These moments fit nicely with Messenger's insistence that the focus of contemporary sports fiction is the negotiation between the demands of a collective and the individual's desire to play:

The sports hero or player often desired the "play back to," the desire merely to feel his or her body as a smooth-running whole or to "get back to" the elements of sport before it was taken over in his or her life by patriarchs, coaches, fans, leagues, and schedules. (18)

Caillois proposes that playful activities share several characteristics: they are separate from everyday life, voluntary, governed by a finite set of rules, uncertain in outcome, and unproductive-while goods may be exchanged, as in games of gambling, no wealth is created by play itself. ${ }^{3}$ Wallace himself has pointed to "a level of abstraction and formality" (Supposedly Fun Thing 235n.40) as the defining characteristics of play-a far simpler definition that still implicitly echoes structuralist thought. ${ }^{4}$ In their focus on the corruption of play by various sportsrelated structures, both Universal Baseball Association and End Zone assume the existence of this "pure" ludic space. While clearly indebted not only to these two novels but also to the broader tradition of postmodern sports fiction, Infinite Jest complicates the division between pure and corrupted play that fuels their central conflicts. Reading Infinite Jest, we cannot speak of play as corrupted by sports; sports and play are depicted throughout the novel as entirely discrete endeavors.

\begin{abstract}
Absent Play
The strange athletic career of Orin Incadenza, Hal's older brother and James's eldest son, illustrates the separation of sports and play central to Infinite Jest. Formerly an elite tennis player at E.T.A., Orin is now a punter for the Arizona Cardinals of the National Football League. Throughout Orin's athletic career, sports and play remain two separate endeavors. Furthermore, despite Messenger's claim that athletes in the postmodern literary tradition "wish to 'play back to' the origins of their physical delight" and mourn the restrictive structures imposed by organized sports, Orin neither embraces opportunities to play nor expresses nostalgia when those opportunities are denied (17-18). Orin's participation in both tennis and football satisfies neither structuralist nor poststructuralist definitions of play. Furthermore, his engagement with the games themselves is never governed only by the explicit rules of the sport; Orin's "play" is instead regulated by a surplus of structures featuring a surplus of rules.
\end{abstract}


As Caillois argues, if play is truly to be a free activity then the player must choose when it begins and ends: "It is necessary that [players] be free to leave whenever they please, by saying, 'I am not playing any more"' (6). But Orin's decision to leave E.T.A. at the age of seventeen, effectively dropping out of the world of elite tennis, is not a freely determined action. Instead, it is wholly due to his comparatively low ranking (in the top eighty of junior tennis players nationwide). The narrator refers to this point in Orin's career as "that awful age for a low-70s player where age eighteen and the terminus of a junior career are looming" (283). Orin's "failure" is not a product of his achievement (or lack thereof) but rather of the game's institutional structure; "mediocrity is relative in a sport like junior tennis," and college coaches are still eager to have Orin on their squads (284). His decision to attend Boston University is made mostly by his mother, who "privately thought it was important for Orin to be away from home, psychologically speaking, but still to be able to come home whenever he wished" (285).

The involvement of Orin's family in his athletic career illustrates not only his lack of autonomy but the entanglement of sports with his everyday life. Three weeks into his career at B.U., Orin decides to quit the tennis team and join the football team. As Orin rationalizes the move to his parents, he claims that he no longer has the urge to be a sports star; he is burned out from a life of "playing, eating, sleeping, and excreting competitive tennis" (289). According to Orin's explanation, his play drive has been extinguished by the structures of competitive tennis, a regrettable if understandable consequence of the intense tennis training to which E.T.A is devoted. Football, he claims, might reenergize him, and he catalogues its appeal in aesthetic terms, clearly echoing the prose of Grantland Rice and other early-twentieth-century sportswriters: "the crash of pads and Sisboomba of Pep Squad and ambience of male bonding and smell of dewy turf at Nickerson Field at dawn when he showed up to watch the sprinklers come on and turn the lemon-wedge of risen sun into plumed rainbows of refraction" (289). In other words, Orin just wants to "play" again, to take part in something unproductive, unpredictable, and even beautiful.

If this explanation was true, then Orin's decision to join the football team becomes a celebration of the power of play, and we might read Infinite Jest as a critique of sports institutions that quash the play spirit. But Orin's real rationale for leaving tennis has nothing to do with his well-formulated explanation. That he so easily placates his parents illustrates how deeply the concept of the play drive is entrenched in the popular understanding of contemporary sport; that his explanation is false illustrates the incomplete nature of that understanding. In reality, Orin's decision has nothing to do with tennis or football, but rather with a woman, Joelle Van Dyne, who represents the ultimate in sexual conquests-Orin and his roommate have dubbed her "P.G.O.A.T.", or the "Prettiest Girl of All Time" (290). ${ }^{5}$ When they meet, Orin tells Joelle that football's hold on him is not athletic but "spiritual," characterizing the noise of the crowd as a "coital 
moan, one big vowel, the sound of the womb" (295). Although Orin's conflation of Joelle and his mother is clear throughout the text, this passage demonstrates how deeply Orin's sexual desire for both his mother and Joelle permeates his activities on the football field. As he continues to play, the narrator remarks that he is motivated by "the twin inducements of a gleaming baton and a massive developmental carrot he hadn't felt since age fourteen" (293). The phallic character of this "carrot," a term frequently used by the narrator to describe attempts to motivate E.T.A. students, further conflates sex and sports. In Orin Incadenza's athletic career, we can never speak of sports as separate from everyday life; it is never, as Huizinga insists that play must be, disinterested (9).

By tracing Orin's path from elite tennis to collegiate football, we see that his pursuit of sport is never a voluntary activity, that it is inseparable from his everyday life, and that he views it primarily as a productive enterprise-in this case, producing the chance to gain access to the "Prettiest Girl of All Time." Can we describe his performance within sport as "unpredictable," another characteristic of play as outlined by Caillois? The unpredictability of sport is firmly ensconced in our cultural imagination; the belief that "anything can happen" is one aspect of sport that makes it such a fertile ground for narration. As presented in Infinite Jest, however, sports are surprisingly predictable. From his first punt, Orin is extraordinarily gifted, and as his career progresses he becomes almost mechanistic in his precision. Like many tennis players, as the narrator explains, Orin had always harbored a distaste for football, precisely because it seemed so chaotic: "[he] found the misshapen ball's schizoid bounces disorienting and upsetting to look at" (289). But Orin quickly overcomes these limitations, and only a few games into his career he is "regularly placing his punts inside the opponents' 20, spinning the ball off his cleats' laces so it either hit and squiggled outside the white sideline and out of play or else landed on its point and bounced straight up and seemed to squat in the air, hovering and spinning [. . .]" (294). Orin's punts are not merely spectacular but also incredibly consistent, never subject to the supposedly random bounces that can turn a great kick into a horrible one. The punt has become another form of Orin's masterful tennis lob shot-with which he can "three times out of four nail a large-sized coin placed on the opposite baseline" (284). He "was still only lobbing," as Schtitt, his tennis coach at E.T.A., observes while watching one of Orin's football games on tape (293).

The banal predictability of sport throughout Infinite Jest further undermines the possibility of sports as a site for play. Orin's first punt, necessitated when he wants to return an errant ball to the field without having to walk back (he has just embarrassed himself trying out for the team) is a stock scene in sports narratives, the highly unpredictable and dramatic moment in which an unknown discovers a hidden and surprising talent. In many sports narratives, Orin's punt would be the key scene. (Consider, to name just one example, Roy Hobbs's explosive home run in Bernard Malamud's The Natural, a dramatic spectacle set against the backdrop of driving rain and lighting flashes.) But tellingly, Wallace chooses not 
to narrate this moment, describing neither Orin nor the kick. Instead, the reader only learns that onlookers whistled and pointed, and then we flash forward a few days, by which point Orin has already mastered the skill (292). Certainly we can imagine this first punt as play-Orin has no design other than to return the football, he is under no compulsion to kick it any certain way, and the result is not only unforeseen, but also, we imagine, amazing to behold. But Wallace elides this moment from the text, further divorcing his presentation of sport from the field of play.

In his review of the novel, Birkerts suggests that E.T.A. is "a game world, a closed system, but the idea of play has been pumped out of it, and the remaining husk is but a slight barrier against the maniacal forces at large in the world" (108). But Infinite Jest depicts a world in which play does not need to be "pumped out" of sport - the two are already systematically estranged. Throughout, the novel privileges the everyday over the highlight. While individual matches get short shrift, Wallace describes daily drills with painstaking detail:

Drills work like this. Eight different emphases on eight different courts. Each quartet starts at a different court and rotates around. The top four traditionally start drills on the first court: backhands down the line, two boys to a side. Corbett Thorp lays down squares of electrician's tape at the court's corners and they are strongly encouraged to hit the balls into the little squares. Hal hits with Stice, Coyle with Wayne; Axford's been sent down with Shaw and Struck for some reason. (451)

Each of the eight drills receives similar narration, as does the academy's stringent conditioning program. The annual match between E.T.A. and rival Port Washington does garner extensive narrative attention; however, its extreme size-it features 108 matches-makes any individual moment or contest irrelevant, at least from the reader's perspective (259). The sheer volume of tennis "played" at E.T.A. ensures that the sport will not remain separate, as it permeates every aspect of the students' lives. No E.T.A. student goes anywhere without a tennis ball in hand, ceaselessly squeezing it during idle moments to develop forearm strength, "as per academy mandate" (104). The expressed intention of this tennis overload is to turn E.T.A. students into machines capable of making "The Show"; any sense of play is an afterthought, at best. Even in Hal's recurring tennis dream, play and sports cannot fully integrate: "We sort of play. But it's all hypothetical, somehow. Even the 'we' is theory: I never get quite to see the distant opponent, for all the apparatus of the game" (68).

When play does occur in Infinite Jest, it is not on the tennis court or the football field. One might assume, then, that the novel critiques sports but not playthat though play is not where we expect to find it, it remains "an individual's free point where he or she may reign provisionally with dominion over all signifiers but with no ultimate relation to the collective," as Messenger argues (15). Perhaps these moments of play might effectively destabilize the rigid structures that govern life at places like E.T.A. But by associating moments of play with the 
experience of extreme anxiety, Infinite Jest complicates this assumed relationship among play, autonomy, and destabilization.

\section{Anxious Play}

On November 5, Year of the Adult Depend Undergarment (time having been subsidized nine years ago in 2002), Hal sits on his bed, clipping his toenails into a garbage can that sits several meters away. When Orin calls, he finds his brother in the midst of a spontaneously conceived game that appears to provide an excellent opportunity for play. Though Hal's game is ordered (he attempts to propel the toenails into the wastebasket, and the target remains in a fixed position), it does not appear to restrict his autonomy in any other way. It is decidedly separate from the everyday, unproductive and unpredictable, and Hal is a free participant. The game has no other end than its own enjoyment. ${ }^{6}$

Why, then, does Hal experience so much anxiety during this moment of play? He immediately begins to keep statistics, telling Orin that he's "shooting seventy-plus percent," a rate of success that both pleases him and fills him with dread: "I'm actually frightened to switch feet right now. I'm clipping off the tiniest aerodynamically viable clippings possible, to prolong the time on this foot, in case the magic's a function of this foot" (243). The parallels with sport are obvious to both brothers, and Orin begins to detail the paranoia of his N.F.L. teammates, who engage in obsessive rituals before and after games in hopes that they might retain "the magic" to which Hal refers. Even while engaged in a spontaneous game, Hal is susceptible to a form of "agency panic," which critic Timothy Melley defines as "intense anxiety about an apparent loss of autonomy or self-control-the conviction that one's actions are being controlled by someone else, that one has been 'constructed' by powerful external agents" (62). Of course, Hal does not suspect any individual or conspiracy; instead, he merely reflects on the profoundly underdetermined nature of his performance. If he cannot understand why he succeeds, then how will he know how to keep from failing?

However, Hal's brother is preoccupied by exactly the sort of political agency panic that Melley describes. Over the telephone, he tells Hal about his (correct) suspicion that he is being followed: "And now everywhere I go the last several days there seems to be a statistically improbable number of wheelchaired figures around, lurking, somehow just a little too nonchalantly." ${ }^{, 7}$ Both Orin and Hal are disturbed by the improbability of what they are observing-for Orin, a sudden preponderance of confrontations with people in wheelchairs; for Hal, his amazing ability to direct his toenails into a distant garbage can. But Hal's enemy is not a conspiracy directed against him; instead, it is his own compulsion to narrate and keep statistics, to translate (much like Universal Baseball Assocation's Henry Waugh) his ludic game into competitive event. "Talking about it's broken the spell," Hal tells Orin and explains that he has been unable to begin clipping the nails on his other foot: "I've been sitting here on the edge of the bed with my 
right knee up under my chin, poised, studying the foot, frozen with aboriginal terror" (248). No longer is it merely Hal's success at the game he has devised that is at stake. Rather, it is his ability to play at all, an ability compromised by his desire to pursue his game under the matrix of sport.

Throughout Infinite Jest, we see moments of play immediately translated into rigidly structured events that induce anxiety and paranoia rather than autonomy. Ultimately, the novel questions whether play can ever exist as a liberating function, or if it is always inflected by the same sorts of restrictive forces Orin encounters during his athletic career. At E.T.A., the most popular pastime during breaks from the students' rigid schedule is Eschaton, a game both conceived and run by the students themselves. As its name suggests, the game is concerned with the end of the world, and it simulates geopolitical doomsday scenarios in which players represent different countries, each of which has its own arsenal of five-megaton nuclear warheads. Eschaton, as our narrator explains, is "the most complicated children's game anybody around E.T.A.'d ever heard of," requiring

eight to twelve people to play, w/ 400 tennis balls so dead and bald they can't even be used for service drills anymore, plus an open expanse equal to the area of four contiguous tennis courts, plus a head for data-retrieval and coldly logical cognition, along with at least 40 megabytes of available RAM and wide array of tennis paraphernalia. (322)

In their quest to provide both an accurate geopolitical simulation and satisfying game play, E.T.A. students construct a game that is overwhelmingly rational. Even the relative apportionment of game balls, which used to be determined by a throw of Yahtzee dice, is now determined by a software program called "EndStat"; "quaint chance" as our narrator terms it, is no longer necessary (323). This "game" is serious business, and its players are determined "not to let the awesome weight of their responsibilities—responsibilities to nation, globe, rationality, ideology, conscience and history [. . .] compromise their resolve to do what they must to preserve their people's way of life" (327).

Play, if it exists at all in this game, is the play of make-believe, and Eschaton's creators and participants are all preoccupied with the challenge of generating a simulation with as much verisimilitude as possible. Throughout the early stages of the game, the players are described as eminently "rational" agents, "deliberate," "sober," "judicious," and "almost Talmudic" (327). To play Eschaton is not to challenge its limits, but rather to act with as much efficacy as possible within its rules and structure. As the game-master, the aptly named Otis P. Lord is assumed to act with benign rationality, a disinterested referee charged with the mastery of calculus and game theory that is the game's lifeblood. The game's one aspect of irrationality would appear to be its reliance on the physical propulsion of tennis balls toward enemy targets-the skill required, the narrator suggests, is what "separates Eschaton from rotisserie-league holocaust games played with protractors and PCs around kitchen tables" (324). Yet this element of chance is 
much more predictable than it might appear; we know that many of the athletes at E.T.A. have developed incredibly precise lob shots. ${ }^{8}$ Orin's expertise at lobbing has translated to success as a punter in the N.F.L.; current student Michael Pemulis "can nail a coin on the baseline two out of three times off either side" (324).

Infinite Jest describes in great detail one exceptionally eventful game of Eschaton, held on Interdependence Day ${ }^{9}$ in early November, devoting over twenty pages to the event. In this particular contest, it is not the world that ends but rather Eschaton itself, as the rules are violated in a manner that disrupts the game's controlling fantasy - the construction of Eschaton as a closed system, an entirely discrete alternate reality. This assumption leads the older students watching the game to mock J. J. Penn when he (as Pakistan) bombs Israel—though geopolitically feasible in the "real" world, the move has no strategic value in this particular game. As the narrator reminds us, "It is not a matter of the principle of thing [sic], ever, in Eschaton" (328). As caretakers of Eschaton (Michael Pemulis is credited by the narrator for making the game "way more compelling"), the game's spectators feel obligated to continually reassert the distinction between simulated game and real life (322).

On Interdependence Day, these painstakingly erected boundaries between the real and the simulated collapse. Hopelessly behind in the game, J. J. Penn conflates the two, claiming that the real falling snow should be accounted for in the calculation of simulated missile strike damage. The chaotic argument that ensues is fueled not only by the older players' fervent desire to maintain the game's boundaries, but also by the "real" feuds, rivalries, and animosities that intrude into the "simulated" system. Pemulis, Penn's most vocal critic, is "a sworn foe of all Penns for all time," his hatred generated by the harassment meted out by J. J.'s older brother Miles when Michael was an eleven-year-old newcomer to the academy (333). Penn and Kieran McKenna start firing tennis balls (which are supposedly five-megaton nuclear warheads "too precious to waste on personal attacks outside the map") at Ann Kittenplan because they both have "longstanding personal bones to pick" with her $(336,340)$. Evan Ingersoll is bombarded by everyone in the game because all the participants have begun to sense that he is "fair game for cruelty - the way kids can seem to smell this sort of thing out with such uncanny acuity" (340). In short, all sorts of "nonstrategic emotions" are aroused, and ironically, the melee that results is a much more accurate "simulation" of war than the game itself (338).

Despite Eschaton's eventual disintegration, the novel commits considerable space to its complex setup, a complexity in part intended to ensure that the boundary between the game and the "real world" remains absolute. Though Eschaton's extraordinary intricacy ensures it will be played infrequently, these same anxieties about the boundaries surrounding play recur in everyday activities throughout the novel, most notably in Ken Erdedy's ritualistic use of marijuana. Although most of the novel finds Erdedy in drug treatment at the Ennet House, a flashback reveals the exceptional degree to which he felt he had to isolate himself in order to smoke pot: 
He had to modem in to the agency and say that there was an emergency and that he was posting an e-note on a colleague's TP asking her to cover his calls for the rest of the week because he'd be out of contact for several days due to this emergency. He had to put an audio message on his answering device saying that starting that afternoon he was going to be unreachable for several days. He had to clean his bedroom, because once he had dope he would not leave his bedroom except to go to the refrigerator and the bathroom, and even then the trips would be very quick. [. . . He had already vacuumed his Venetian blinds and curtains, everything was ready to be shut down. Once the [dealer] had come, he'd shut the whole system down. (19-20)

Drug use, though indulged in by many characters, is never celebrated in Infinite Jest. What might be represented as a playful liberation from the prevailing order is instead characterized as a profoundly banal, anxious, and isolating enterprise. Like Erdedy, Hal Incadenza must hide his marijuana use- - he does so by crawling through the academy's defunct system of underground tunnels into a small room that houses little more than an exhaust fan; the narrator notes that "he's as attached to the secrecy as he is to getting high" (49). Drug use, rather than destabilizing controlling structures, compels both Hal and Erdedy to surround themselves with more boundaries and limits. Erdedy's regimented approach to his long weekend of smoking ("200 or 300 bong hits a day" over four days) is described in workmanlike language as a "mission," a "penance," and an attempt at "behavior-modification" (22). Erdedy plans to smoke such an exceptional amount of pot in order to "cure himself by excess"; his final experience with marijuana will occur inside the boundary of four days. This boundary proves flimsy; Erdedy has tried to quit via this and a host of other techniques "maybe 70 or 80 times before" (18).

Several critics, pointing both to the novel's skeptical portrayal of drug use and to the chaotic breakdown of Eschaton, have read Infinite Jest as an argument for structures and limits. Timothy Jacobs reads the Eschaton crisis as an allegory for problems with contemporary fiction, arguing that the novel's "thesis" is that "literature produced without boundaries results in chaotic and solipsistic expression" (223). Catherine Nichols explicitly opposes the novel to the transgressive tradition of the literary carnivalesque, claiming that in the world of Infinite Jest "sober reality becomes an even more revolutionary act than deliberately seeking out its distortions" (6). Neither reading leaves much room for play to exist in the novel as anything more than evasion and solipsism. But despite its obvious skepticism towards the possibility of play (especially in the places our culture most expects to find it), Infinite Jest engages in both linguistic and formal play to an extraordinary degree. Describing the novel as "prodigious," Tom LeClair points out just a few of these narrative flourishes: "multiple points of view, both first- and thirdperson; stylistic tours de force in several dialects; a swirling associative structure; and alternations in synecdochic scale" (35). As many have noted and several quotations in this essay indicate, Wallace's prose style spans a diverse array of discursive registers; the narrator is just as likely to needlessly (and repeatedly) 
insert "like" into a passage as to coin a neologism or to outline the finer points of annular fission. Three hundred eighty-eight "footnotes," which appear at the end of the text, move the novel even further from linear narration; some provide crucial information while others are extraneous, at best. ${ }^{10}$ Katherine Hayles describes this form as "cycles within cycles within cycles" in which "any starting point would be somewhat arbitrary" (684). "Arbitrary" and "swirling," the novel's narrative technique is clearly indebted to the play impulse-suggesting that Infinite Jest's apparent thematic sobriety must be decidedly more complex.

\section{Serious Play}

A recovering alcoholic and drug addict, Don Gately has been sober for over a year when most of the action in Infinite Jest occurs. His commitment to sobriety is so complete that he refuses any potentially addictive painkilling medication during his treatment and recovery after he is shot in a fight with Canadian terrorists outside of the Ennet House. Gately acknowledges that he owes his recovery from addiction to his relationship with Alcoholics Anonymous, a significant narrative focus throughout the novel. This fascination with AA, described by the narrator as an "Irony-free zone," appears to provide more evidence for the readings of Nichols and Jacobs in which Infinite Jest fervently endorses sincerity (369). Jacobs, reading both the novel and a 1993 interview with Wallace, identifies a clear divide between "unself-conscious" moments and "purposeless irony" in the text, arguing that Wallace unabashedly celebrates the former (216). But Gately's ongoing struggle to accept AA doctrine (a struggle that continues as he lies in his hospital bed) highlights the difficulty of distinguishing between the sincere and the ironic. The novel's depiction of Alcoholics Anonymous complicates this binary and explores the potential of the partial and playful mode of identification endorsed by Donna Haraway in "A Cyborg Manifesto."

The first Alcoholics Anonymous episode in Infinite Jest directly follows the disastrous game of Eschaton discussed above. At first, AA seems governed by structures as rigid and artificial as those of Eschaton-not only the twelve steps but also "about a dozen basic suggestions" that usually take the form of clichés such as "Live and Let Live!" $(356,358)$. Yet when Gately tries to convince new Ennet House residents of the program's merits, he emphasizes the freedom it allows: "Nobody can get kicked out, not for any reason. Which means you can say anything in here" (352). Indeed, this chapter of AA takes particular pride in its lack of rigidity, a stark contrast to the self-imposed and arbitrary rules through which addicts like Ken Erdedy attempt to manage their substance abuse; the narrator notes that alcoholics about to hit bottom are particularly fond of "superstructures of additional self-regulations (e.g. not before 0900h. not on a worknight, only when the moon is waxing, only in the company of Swedes)" (346).

Puzzled by the fact that "these AA meetings where nobody kept order seemed so orderly," Gately suspects that the program's structure is more ideological than 
repressive (357). He frequently struggles with the banal aphorisms that constitute much of each meeting's discourse, voicing his displeasure at a meeting during his first month of sobriety:

[Gately said] just how much he hates this limp AA drivel about gratitude and humility and miracles and how he hates it and thinks it's horseshit and hates the AAs and how they all seem like limp smug moronic self-satisfied shit-eating pricks with their lobotomized smiles and goopy sentiment. [...] (353)

Though Gately has certainly grown less hostile toward AA since that first month, he still feels that "old and almost unfamiliar panic" when another Ennet House resident points out the lack of syntactical meaning in "I'm here But For the Grace of God," one of AA's principal axioms (366). He also still struggles with the suggestion that he pray twice a day to some form of higher power, confessing in a meeting that he still cannot conceptualize a god "to really sincerely pray to" (444). Despite these struggles, Gately has been sober for 426 days at the time he is shot, and though the narrative is ambiguous, he appears to survive his trip to the hospital without being treated with Demerol. Yet Gately's philosophical reservations regarding AA dogma do not disrupt his continuous sobriety-a sobriety he repeatedly acknowledges would not be possible without AA.

Gately's success with AA is generated not by the program itself but rather by his provisional and playful approach to it. Rather than conceiving of AA as an opportunity for revelatory self-examination, Gately constructs the program as precisely the sort of closed ludic space that has eluded the novel's other characters. Unlike Orin and $\mathrm{Hal}$, who are unable to untangle their sports careers from their "real" lives, Gately segregates his AA activities both physically and philosophically from his everyday life. This strategic construction of a provisional identity echoes Haraway's description of simulated politics in "A Cyborg Manifesto," in which she espouses the potency of hybrid identities and partial identifications. She describes the cyborg as a subject "resolutely committed to partiality, irony, intimacy, and perversity" that crafts multiple identities through irony and serious play (151). AA's “'Fake It Till You Make It"” suggestion encourages a similarly serious form of play, in which Gately separates his words and actions from his "true" feelings; as an atheist, he must do this to meet the program's dictum to pray twice a day. Gately's mentors repeatedly assure him that it doesn't matter whether he "sincerely" believes in the program: "Pat had said it didn't matter at this point what he thought or believed or even said. All that mattered was what he did" (466). The narrative Gately constructs to describe his daily prayers reveals this ambiguation between prayer and play:

He feels about the ritualistic daily Please and Thank You prayers rather like like [sic] a hitter that's on a hitting streak and doesn't change his jock or socks or pre-game routine for as long as he's on the streak. W/ sobriety being the hitting streak and whatnot, he explains (443). 
Of course, this passage also reveals the paranoia produced by the disjunction between thought and action these prayers require, and Gately is not immune to the anxieties that play produces throughout Infinite Jest. The novel's refusal to silence these anxieties allows it to explore the difficulties inherent in a playful and provisional approach to identity with much more thoroughness than Haraway's manifesto mode affords. But while Hal, for instance, reacts to this anxiety with fearful paralysis, Gately continues to "Stay Active" (another AA aphorism), continuing to pray, attending nightly meetings, and speaking at AA sessions throughout the Boston area. Ironically, Gately feels most free within the same meeting rooms that are festooned with the "trite but correct" slogans he detests - as mentioned above, he frequently takes advantage of AA's tolerant environment to air his distaste for the program (291).

Although Gately clearly constructs AA as a ludic space separate from his everyday life, it is by no means a utopia. Although he gains independence from his addictions to alcohol and Demerol, he must relinquish any conception of himself as an integrated and autonomous subject. Initially worried that AA constitutes a form of brainwashing, Gately decides that "the old brain needed a good scrub and soak anyway," acknowledging the significant portion of his own subjectivity still under the control of addiction (369). Hayles reads Gately's transformation as a move away from the ideology of a liberal subject "free to engage in the pursuit of happiness [. . . ] without regard for the cost of that pursuit to others" towards an acknowledgment of citizenship in an interconnected world (693). While this argument certainly describes an effect of Gately's transformation, it does not account for the playful method by which he achieves it. Gately's most important revelation is not the existence of other people, but rather of the multiple "selves" that constitute his identity. The change is not ontological-Gately is still an addict and still does not believe in God; instead, it is provisional-he strategically constructs a self that can comply with all of AA's "suggestions."

Gately's "playful" recovery becomes an excruciating battle as he convalesces from a gunshot wound without the benefit of painkillers. Throughout his struggle for sobriety, Gately recognizes that he is both working and playing. In contrast, the novel's failed attempts at play are doomed by their construction of play in opposition to work, to "real" life, to the everyday, or to all three. Infinite Jest does not privilege play, but neither does it condemn it. Instead, it contrasts strategic, provisional, and ultimately liberating play with the naive idealization of play as a haven for autonomy, free from the regulatory structures of everyday life. Both Don Gately's recovery from drug and alcohol addiction and the novel's adventurous prose and form illustrate the potency of serious play.

\section{UNIVERSITY OF IOWA IOWA CITY}




\section{NOTES}

1. Birkerts attributes much of the novel's focus on tennis to Wallace's biography. A gifted junior tennis player, Wallace discusses his athletic career in "Derivative Sport in Tornado Alley," the first essay in his collection A Supposedly Fun Thing I'll Never Do Again (1997).

2. There are a number of more explicit correspondences between End Zone and Infinite Jest. The protagonists of both novels are exceptionally literate and articulate athletes with marijuana habits; both feature extended set pieces focusing on geopolitical simulations; both Logos College and E.T.A. boast itinerant sportscasters (Raymond Toon and Jim Troeltsch) who narrate important athletic events within the novel.

3. Of course, Caillois acknowledges that professional players (e.g., athletes, actors, and musicians) use play as a means of gaining wealth, but he argues that this constitutes a transition from "playing" to "working": "When they play, it is at some other game" (6). For a more complete development of these criteria, see the chapter "Definition of Play" in Man, Play, and Games.

4. The citation is the piece briefly alluded to in this essay's introduction, the extravagantly titled "Tennis Player Michael Joyce's Professional Artistry as a Paradigm of Certain Stuff about Choice, Freedom, Limitation, Joy, Grotesquerie, and Human Completeness." This essay, along with "Derivative Sport in Tornado Alley" and "How Tracy Austin Broke My Heart," reprinted in Consider the Lobster (2005), provides a fascinating look at Wallace's thoughts on tennis as he wrote Infinite Jest. These texts should not be conflated, however; the novel is a much more thorough and complicated reworking of many of the themes that the three essays explore.

5. When Orin tells the nameless B.U. tennis coach he is leaving the team, the coach starts to cry, continually asking "if this meant Orin's mother wouldn't be coming down to watch practice anymore" (290). Given Avril's figuration as an object of desire for most of the book's main characters, the coach's response indicates that he is motivated more by sexual desire than by competitive concerns. These desires are further highlighted by his prominently displayed poster of Bill Tilden, a former tennis champion twice arrested after sexual encounters with teenage boys.

6. Of course, one could point out the functional and quotidian nature of clipping one's toenails. But the clipping itself is not the game; instead, Hal creates the game when he decides to try to direct as many of the nails as possible into the distant wastebasket.

7. Orin refers to the wheelchair-bound Québécois separatists of Les Assassins des Fauteils Rollents (A.F.R.), who ultimately capture and torture him in their pursuit of the Infinite Jest entertainment.

8. The narrator notes that the reason academy administration permits students to play Eschaton is that "the game's devotees tend to develop terrific lobs" — even this apparently bizarre political simulation has been integrated into the everyday work of E.T.A. (324)

9. Interdependence Day celebrates the formation of the Organization of North American Nations (O.N.A.N).

10. The final note in the book, for example, provides a tidbit of questionable use to the reader: the fact that "Talwin-NX" is a registered trademark of Sanofi Winthrop, one of the many pharmaceutical giants that populate the world of Infinite Jest.

\section{WORKS CITED}

Birkerts, Sven. “The Alchemist's Retort.” The Atlantic Monthly. February 1996: 106-08.

Caillois, Roger. Man, Play, and Games. Trans. Meyer Barash. New York: Free Press of Glencoe, 1961.

Caldwell, Roy C. Jr. “Of Hobby-Horses, Baseball, and Narrative: Coover's Universal Baseball Association. Modern Fiction Studies 33.1 (1987): 161-71.

Coover, Robert. The Universal Baseball Association, Inc. J. Henry Waugh, Prop. New York: New Amer. Lib., 1968.

DeLillo, Don. End Zone. New York: Houghton, 1972.

Derrida, Jacques. Writing and Difference. Alan Bass, trans. Chicago: Chicago UP, 1978. 278-94.

Haraway, Donna. Simians, Cyborgs, and Women: The Reinvention of Nature. New York: Routledge, 1991.

FALL 2008, VOL. 50, NO. 1 
"A Cyborg Manifesto: Science, Technology, and Socialist Feminism in the Late Twentieth Century." Simians, Cyborgs, and Women: The Reinvention of Nature. 149-81.

Hayles, Katherine N. "The Illusion of Autonomy and Fact of Recursivity: Virtual Ecologies, Entertainment, and Infinite Jest." New Literary History 30.3 (1999): 675-97.

Huizinga, Johan. Homo Ludens. Trans. R. F .C. Hull. 1938. London: Routledge and Kegan Paul, 1949.

Jacobs, Timothy. "American Touchstone: The Idea of Order in Gerard Manley Hopkins and David Foster Wallace.” Comparative Literature Studies 38.3 (2001): 215-31.

LeClair, Tom. "The Prodigious Fiction of Richard Powers, William Vollmann, and David Foster Wallace." Critique 38.1 (1996): 12-37.

Melley, Timothy. Empire of Conspiracy: The Culture of Paranoia in Postwar America. Ithaca: Cornell UP, 2000.

Messenger, Christian K. Sport and the Spirit of Play in Contemporary American Fiction. New York: Columbia UP, 1990.

Nichols, Catherine. "Dialogizing Postmodern Carnival: David Foster Wallace's Infinite Jest." Critique 43.1 (2001): 3-16.

Wallace, David Foster. Consider The Lobster. New York: Little, Brown, and Co., 2005.

"Derivative Sport in Tornado Alley." A Supposedly Fun Thing I'll Never Do Again. 3-20.

. "How Tracy Austin Broke My Heart." Consider the Lobster. By David Foster Wallace. New York: Little, 2005. 141-55.

. Infinite Jest. Boston: Little, 1996.

. A Supposedly Fun Thing I'll Never Do Again. Boston: Little, 1997.

. "Tennis Player Michael Joyce's Professional Artistry as a Paradigm of Certain Stuff about Choice, Freedom, Limitation, Joy, Grotesquerie, and Human Completeness." A Supposedly Fun Thing I'll Never Do Again. 213-255. 